\title{
19
}

\section{Water Quality Modeling using Fault Tree Method}

\section{Jinhui Jeanne Huang and Edward A. McBean}

The need for increased diligence in identifying pathogen-related outbreaks is demonstrable. In response, a fault tree methodology based on water quality failure mechanisms is developed to quantify the exposure of the water quality failure risk. The method is shown to provide an index to assist in locating on-line sensors within water distribution systems. The use of a combination of sensors is proposed for microbial detection in water distribution systems and a Bayesian classification method, in conjunction with a data mining procedure, to evaluate these sensor data and develop inferences whether pathogen excursions are causing exposure hazards in water distribution system.

\subsection{Introduction}

"High quality water is more than the dream of the conservationists, more than a political slogan; high quality water, in the right quantity at the right place, at the right time, is essential to health, recreation, and economic growth." (Edmund S. Muskie, U.S. Senator; speech, March 1, 1966).

Drinking water systems are designed to provide a consumable product that has long been considered as essential to people's daily life, and to promote economic growth. In fact, widespread availability of chlorinated water

Huang, J. and E. McBean. 2007. "Water Quality Modeling using Fault Tree Method." Journal of Water Management Modeling R227-19. doi: 10.14796/JWMM.R227-19.

(C) CHI 2007 www.chijournal.org ISSN: 2292-6062 (Formerly in Contemporary Modeling of Urban Water Systems. ISBN: 0-9736716-3-7) 
precipitated the most important improvement in human health that has occurred throughout modern history.

For a water supply system to be considered reliable, the following must occur:

1. meet the water demand;

2. be delivered at sufficient pressure; and

3. be safe for use.

Failure to meet these criteria constitutes 'risk' to potable water supply. Failures to meet the above three criteria include mechanical failure, hydraulic failure, and water quality failure (Huang et al., 2004). These three failure types are not independent. For example, a water distribution system may be contaminated by bacterial intrusion (water quality failure) through cross-connections or back-siphonage, or by leakage ingress after pressure loss (hydraulic failure) due to a pump failure (mechanical failure). As well, ingress of water and sediments (water quality failure) may further deteriorate the system supply components (e.g. pipes and valves), increasing the probability of mechanical failure. Hence, to address failure potential, it is necessary to understand the failure mechanisms, and assurance of a robust operating water distribution system requires protection of people from unacceptable exposure risks.

In many respects, the distribution system has the greatest vulnerability for failure of the many components within a potable water supply system. For example, the water leaving the water treatment plant may be of high quality, but subject to deterioration within the distribution systems due to factors including, but not limited to, contaminated water ingress through system components failure (e.g. integrity was compromised, misused, cracked or broken), and leaching of chemicals and corrosion products from system components.

Of these failure scenarios, ensuring delivery of microbiologically safe water is one of the most difficult elements. For the two-year period 1993 and 1994, a total of 30 outbreaks associated with drinking water were reported in seventeen states and one territory in the U.S., and resulted in an estimated 405,366 persons becoming ill. These impacts included 403,000 from an outbreak of cryptosporidiosis in Milwaukee, the largest waterborne disease outbreak ever documented in the United States (Kramer et al., 1996). In Walkerton, Ontario, Canada with a population of 4800, the outbreak of $E$. Coli O157:H7 and Campylobacter jejuni occurring in May 2000 via contaminated drinking water, killed seven persons, and resulted in more than 2,300 persons becoming ill (Ministry of the Attorney General of Ontario, 2002). 
As an indication of the small quantities needed to create a microbiological outbreak, Rose (2002) reported that a $10 \%$ chance of rotavirus infection occurs when 1 liter of water is consumed per person, with only $1 \mathrm{~g}$ of feces mixed in 3.785 million litres of water. Conversely, as reported by Perz et al. (1998), only three out of 10,000 infections by cryptospiridium are actually reported, which indicates the number of infections may be much greater than acknowledged. As a further demonstration of the awareness issue, depicted in Figure 19.1 are the numbers of waterborne outbreaks in Canada, as reported by Schuster et al., (2005). Of note is the substantial increase in the plotted annual numbers of outbreaks starting in 1990; however, rather than representing a change in the actual numbers of outbreaks, the increased numbers in Figure 19.1 instead represent improved identification of occurrences of outbreaks. Increased diligence of reporting, and improved monitoring of pathogen levels, will improve the understanding of exposure scenarios and the merits of alternative measures to control human exposures to pathogens.

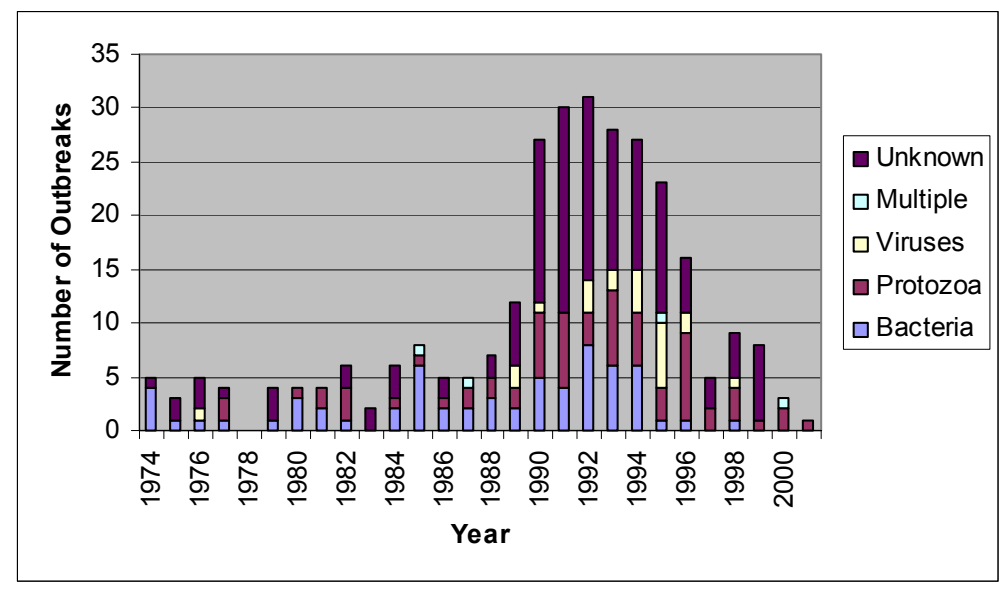

Figure 19.1 Outbreaks in Canada (Schuster et al., 2005).

An important element of the needed framework for controlling exposure scenarios is related to the difficulty of monitoring pathogen levels. Existing pathogen monitoring techniques are expensive (e.g. C $\$ 1200$ for a cryptospiridium analysis), and the timeframe for obtaining the results is substantial. The need exists for in-situ monitoring in water supply 
distribution systems with sufficient frequency in space and time to allow response to the exposure risks in a timely fashion, to protect consumers against waterborne disease and other water quality failures.

This chapter investigates water quality failure mechanisms in water distribution systems. A fault tree methodology is developed, to quantify water quality failure risks based on the failure mechanism. The use of a combination of instantaneous sensors in microbial detection is proposed. A Bayesian model should incorporate the sensor recordings to determine whether pathogens are present in water distribution systems.

\subsection{Water Quality Failure Mechanisms in Water Distribution Systems}

\subsubsection{Failure Mechanisms}

Many factors may cause water quality deterioration in water distribution systems. Table 19.1 lists examples of waterborne diseases experienced in Canada since the 1980s. The sources of these waterborne diseases are varied, including wildlife and sewage, and improper back flushing.

While broad-ranging, contamination ingress is particularly challenging. Tables 19.2 and 19.3 list examples of contamination incidents, indicating that contamination ingress may be very serious, with many incidents resulting from backflow control failure. While backflow prevention devices function by stopping the reversal of flow, they are not testable once installed (USC FCCCHR, 1998) and have significant variability in cost and effectiveness. The number of backflow incidents reported is considered a small percentage of the number which actually occur (US EPA, 2002).

Further, after September 11, 2001, the potential for purposeful ingress into water distribution system is also raising people's concern. Although the probability of a terrorist threat to drinking water is low, the consequences could be very severe for exposed populations.

Figure 19.2 schematically illustrates the complex mechanisms resulting in water quality failure in water distribution systems as a hierarchical causative network, or water quality failure fault tree. Figure 19.2 indicates that, except for purposeful ingress, all other types of ingress are caused by mechanical failure in water distribution systems. It thus is critical to understand how mechanical failures affect the potential for water quality failure. 
Water Quality Modeling using Fault Tree Method

Table 19.1 Examples of waterborne disease outbreaks in Canada.

\begin{tabular}{|c|c|c|c|c|}
\hline Location & Date & Agent & $\begin{array}{l}\text { Confirmed \# } \\
\text { ill (at risk) }\end{array}$ & Reason \\
\hline Nakusp, BC & $\begin{array}{l}1980 \\
\text { July2-23 }\end{array}$ & $\begin{array}{l}\text { Campylobacter } \\
\text { jejuni }\end{array}$ & 800 & $\begin{array}{l}\text { Wildlife; work on } \\
\text { gravity line }\end{array}$ \\
\hline Banff, AB & $\begin{array}{l}1981 \text { Dec. } \\
1982 \text { April }\end{array}$ & Giardia lamblia & 161 & $\begin{array}{l}\text { Infected beaver in } \\
\text { reservoir }\end{array}$ \\
\hline KimberlyBC & 1982 & Giardia & 3000 approx & Wildlife suspected \\
\hline Drumheller, AB & $\begin{array}{l}1983 \mathrm{Feb} \\
20\end{array}$ & $\begin{array}{l}\text { Norwalk-related } \\
\text { virus }\end{array}$ & 1326 & $\begin{array}{l}\text { Sewage lift station } \\
\text { overflowed }\end{array}$ \\
\hline Orangeville, ON & $\begin{array}{l}1985 \text { April } \\
17\end{array}$ & $\begin{array}{l}\text { Campylobacter } \\
\text { jejuni }\end{array}$ & $>250$ & $\begin{array}{l}\text { Possible frozen animal } \\
\text { wastes in farm ditch; } \\
\text { heavy rain and spring } \\
\text { thaw; unusually large } \\
\text { snowpack }\end{array}$ \\
\hline $\begin{array}{l}\text { Peterview/ } \\
\text { Botwood NFLD }\end{array}$ & $\begin{array}{l}1991 \\
\text { July/Aug }\end{array}$ & Giardia lamblia & 1200 & Infected beaver \\
\hline $\begin{array}{l}\text { Kitchener- } \\
\text { Waterloo ON }\end{array}$ & $\begin{array}{l}1993 \\
\text { March/ } \\
\text { April }\end{array}$ & $\begin{array}{l}\text { Cryptosporidium } \\
\text { parvum }\end{array}$ & 225 & $\begin{array}{l}\text { Probable improper } \\
\text { backflushing of filters; } \\
\text { recent change to surface } \\
\text { water; heavy } 1993 \\
\text { winter melt \& spring } \\
\text { run-off; incomplete } \\
\text { removal/inactivation of } \\
\text { oocysts during water } \\
\text { treatment plant } \\
\text { processes }\end{array}$ \\
\hline Kelowna, BC & 1996 & Cryptosporidium & 177 & $\begin{array}{l}\text { Human sewage or other } \\
\text { human contamination } \\
\text { suspected }\end{array}$ \\
\hline $\begin{array}{l}\text { Walkerton, } \\
\text { ON }\end{array}$ & 2000 May & E-coli O157:H7 & $\begin{array}{l}2300 \\
(7 \text { dead })\end{array}$ & $\begin{array}{l}\text { Farm runoff; heavy rain; } \\
\text { flooding; inadequate } \\
\text { water treatment; } \\
\text { deteriorating distribution } \\
\text { system; GWUDI }\end{array}$ \\
\hline $\begin{array}{l}\text { North Battlefrd, } \\
\text { SK }\end{array}$ & $\begin{array}{l}2001 \text { April } \\
25\end{array}$ & $\begin{array}{l}\text { Cryptosporidium } \\
\text { parvum }\end{array}$ & $\begin{array}{l}\text { estimated } \\
5800 \text { to } 7100 \\
\text { residents } \\
\text { along with } \\
\text { hundreds of } \\
\text { visitors }\end{array}$ & $\begin{array}{l}\text { Oocysts in treated water; } \\
\text { Solids Contact Unit } \\
\text { functioning at a sub- } \\
\text { optimal level after } \\
\text { maintenance }\end{array}$ \\
\hline
\end{tabular}

Sources: (Schuster et al., 2005) 
Table 19.2 Examples of cross connections and ingress issues.

\begin{tabular}{|c|c|c|c|}
\hline Location & Year & $\begin{array}{l}\text { Number of } \\
\text { ill people }\end{array}$ & Cause \\
\hline $\begin{array}{l}\text { Suffolk } \\
\text { County, NY }\end{array}$ & 1974 & 750 & $\begin{array}{l}\text { Backflow from slop sink in high- } \\
\text { rise }\end{array}$ \\
\hline Bailey, CO & 1981 & 6 & $\begin{array}{l}\text { Antifreeze from solar heating } \\
\text { system at a school }\end{array}$ \\
\hline Plantation, FL & 1987 & 49 & $\begin{array}{l}\text { Carbon dioxide from soda } \\
\text { machine at a theatre }\end{array}$ \\
\hline $\begin{array}{l}\text { North } \\
\text { Dartmouth, } \\
\text { MA }\end{array}$ & 1995 & 7 & $\begin{array}{l}\text { Backflow from a soda machine } \\
\text { at dining hall }\end{array}$ \\
\hline Stratford, ON & 2005 & 0 & $\begin{array}{l}\text { Backflow from a car wash } \\
\text { facility }\end{array}$ \\
\hline
\end{tabular}

Table 19.3 Types of incidents reported for acute health impacts.

\begin{tabular}{lc}
\hline \multicolumn{1}{c}{ Source of Contaminant } & $\begin{array}{c}\text { Documented } \\
\text { Incidents }\end{array}$ \\
\hline Homes with individual connections & 55 \\
Apartment buildings or condominiums & 27 \\
Mobile homes & 1 \\
Neighborhoods & 3 \\
Medical sites (hospitals, dental, nursing, blood banks) & 27 \\
Public water systems & 15 \\
Government sites (public buildings, churches) & 24 \\
Restaurants & 28 \\
Office buildings & 18 \\
Other commercial buildings & 66 \\
Recreational sites & 10 \\
Industrial sites & 40 \\
Unknown & 108 \\
\hline
\end{tabular}

Sources: (US EPA, 2002)

\subsubsection{Chlorine Residual and Failure Protection}

An important mechanism for protection against risks of microbiological impacts is provided by provision of chlorine residual within the distribution system. However, pipe wall characteristics contribute to water quality deterioration and chlorine residual dieoff (Wable et al., 1991; Rossman et al., 1994; Eisnor and Gagnon, 2003). Huang and McBean (2006) found that 
wall decay of the chlorine residual was more than ten times the magnitude of decay of the chlorine residual associated with bulk water. Since the characterization of the attenuation of chlorine residual by wall decay for particular applications is very difficult, ensuring that sufficient chlorine residual is present requires in-situ monitoring (Huang and McBean, 2006).

\subsubsection{Fault Tree Methodology to Quantify the Water Quality Failure}

Quantifying the water quality risk or failure for a water distribution system is a complex process. A value or price associated with risk must be applied in helping to make the decision whether a risk is acceptable. Let $\mathrm{E}_{\mathrm{R}}$ denote the expected value of a risk; $E_{R}$ can be determined by Equation 19.1:

$$
\mathrm{E}_{\mathrm{R}}=\sum_{i=1}^{N} R_{V_{i}} R_{F_{i}}
$$

where:

$$
\begin{aligned}
\mathrm{N} & =\text { identified risk events in water distribution systems } \\
\mathrm{R}_{\mathrm{v}} & =\text { the consequence of the risk, and } \\
\mathrm{R}_{\mathrm{F}} & =\text { the frequency or probability of the risk event. }
\end{aligned}
$$

McBean and Rovers (1998) concluded that the magnitude of risk can be characterized into four broad categories:

1. Familiar high risks with good information;

2. Risks of low probability with very large consequences so that they must be taken seriously;

3. An extension of the second category. Although the probabilities of such risks are so low that they have never happened at all yet, the consequences deserve attention; and,

4. A collection of risks which are hard to evaluate because they show up as increases in naturally occurring hazards.

In general, the risks in the first category always have low $R_{v}$ values with high $R_{F}$ values, while the risks in the remaining three categories always have high $R_{v}$ value with a relatively lower $R_{F}$ value. Normally, to quantify $R_{F}$, historical data, domain knowledge, and expert knowledge, are needed. However, very frequently, historical data and domain knowledge on the probability of an acknowledged water quality failure is lacking since the water quality failure is an infrequent event compared with mechanical failure (e.g. pipe breaks, backflow control valve failures, etc.). 


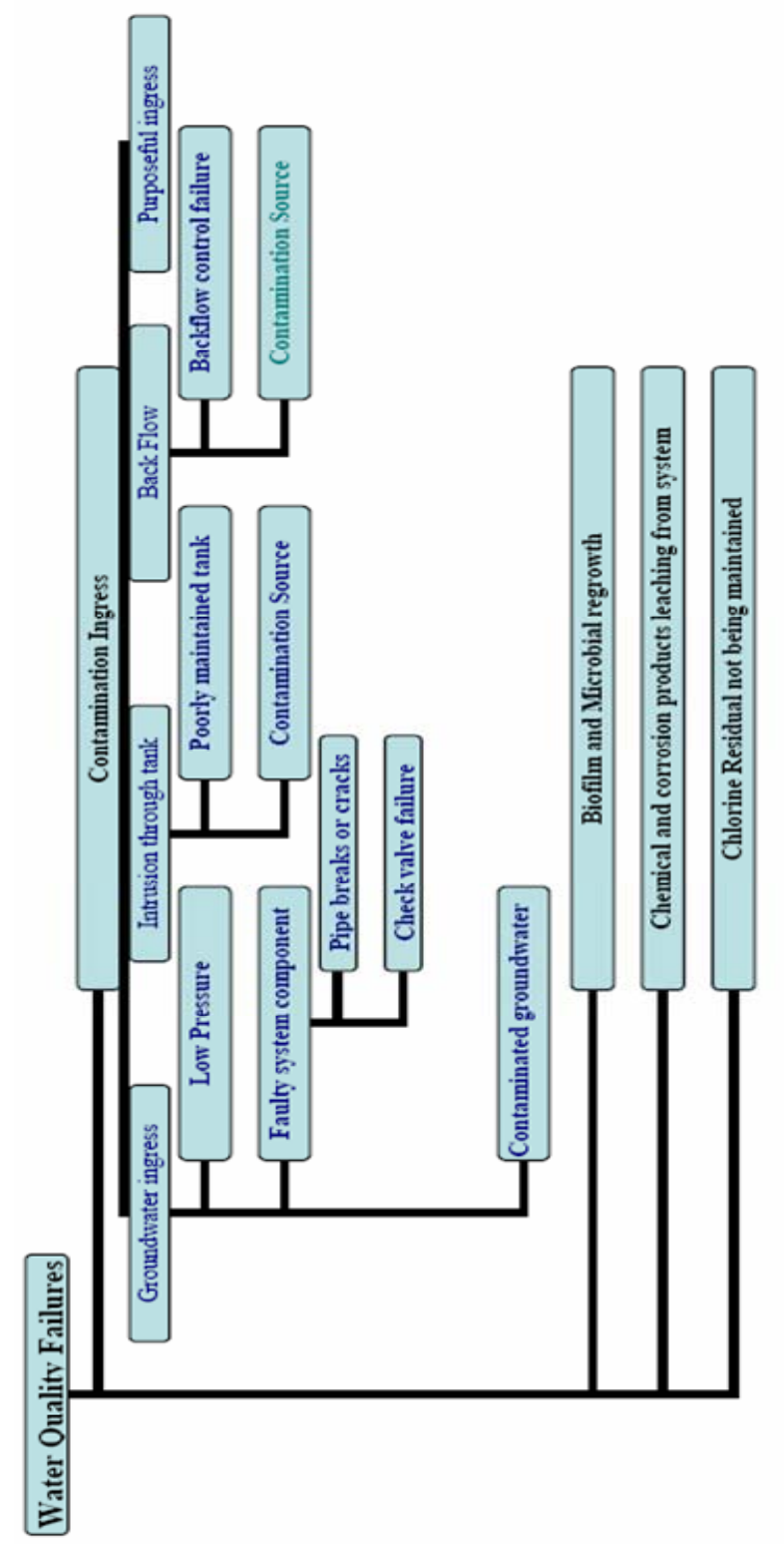

Figure 19.2 Water quality failure mechanisms. 
On the other hand, the knowledge of the water quality failure mechanism may assist the estimation of water quality failure probabilities based on knowledge of mechanical failure probabilities, which are easier to determine from available information (e.g. the age of the component and the repair records).

First, the water quality failure mechanism as shown in Figure 19.2 has identified the cause-and-effect relationship leading to the water quality failure in water distribution systems. Fault Tree Analysis (FTA), which is a bottom-up approach, provides a systematic description of the combinations of possible occurrences in a system which may result in the water quality failure. By ascribing the upper level event to its intermediate lower level events, the probability of the top event, water quality failure, can be obtained. To explain the approach, consider the simple fault tree example of groundwater ingress as depicted in Figure 19.3 which is part of the fault tree shown in Figure 19.2. This fault tree consists of 'AND' and 'OR' gates. There are five basic events denoted by BE1- BE5, which represent (i) low pressure, (ii) contaminated groundwater, (iii) pipe breaks, (iv) cracks in pipe and (v) check valve failure, respectively. One intermediate event, denoted by IE, represents the faulty component is identified, and the top event, groundwater ingress, is denoted by TE. Herein, the domain knowledge, or prior information, is assumed to be available for the basic events only and the information on the intermediate and top events are obtained by employing the Fault Tree Analysis Approach. For OR gates, the probability is the sum of the probabilities of its intermediate lower level events; while for AND gates, the probability is the product of the probabilities of its intermediate lower level events. It is then possible for the higher level event probability to be expressed in terms of basic event probabilities. In this simple example, the probability of groundwater ingress is calculated as:

$$
\mathrm{P}(\mathrm{TE})=\mathrm{P}(\mathrm{B} 1) \times \mathrm{P}(\mathrm{B} 2) \times \mathrm{P}(\mathrm{IE})=\mathrm{P}(\mathrm{B} 1) \times \mathrm{P}(\mathrm{B} 2)(\mathrm{P}(\mathrm{B} 3)+\mathrm{P}(\mathrm{B} 4)+\mathrm{P}(\mathrm{B} 5))
$$

The probabilities of pipe breaks, cracks in pipes, and check valve failure can be established from historical records. The low pressure event can be identified from water treatment plant log data or running water distribution system models for various scenarios. The probability of contaminated groundwater can be estimated from field studies.

Figure 19.3 illustrates the application of fault tree analysis in quantifying the groundwater ingress probability. In this example, the probability of groundwater ingress is $6.2 \mathrm{E}-05$. Although the probability of groundwater 
ingress is much smaller than the component failure probability, because the mechanical failure is the root failure event of the contamination ingress, the increase of the probability of pipe breaks, cracks in pipe and check valve failure, increases the probability of contamination ingress. The probability of other failure events including intrusion from tanks and backflow control failure can be obtained in the same fashion as groundwater ingress.

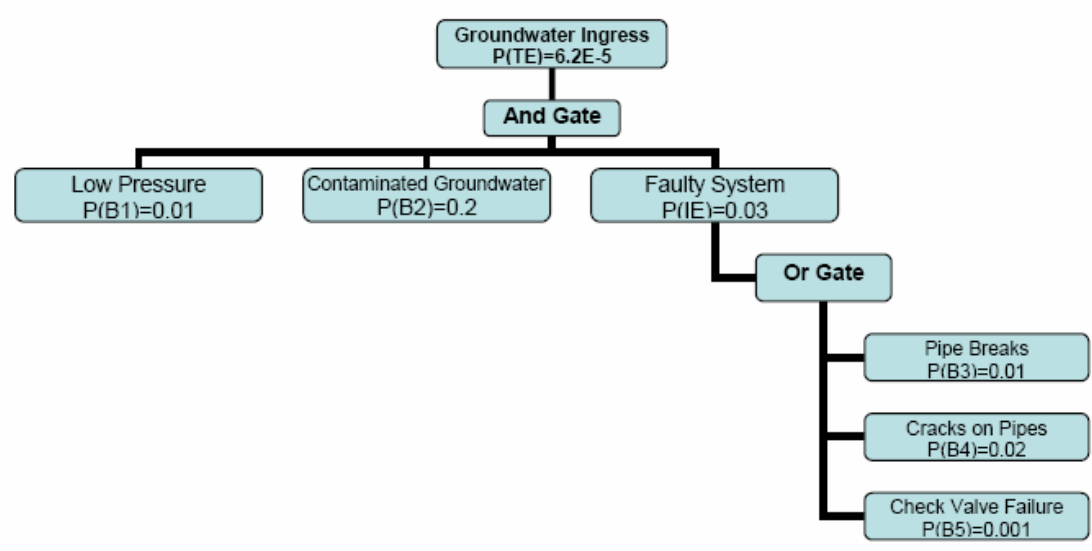

Figure 19.3 Quantification of groundwater ingress fault tree.

As expressed in Equation 19.1, the severity of the water quality events also needs to be incorporated with the consequence of the failure $R_{V}$. For contamination ingress, the consequence $\mathrm{R}_{\mathrm{V}}$ can be determined by the characteristics of the contamination source and the hydraulics of the flow in the water distribution system. Hence, the simple fault tree provides the means of quantifying water quality failure risk and the contributory effects of mechanical failure on water quality failure.

\subsection{Monitoring Methodologies}

The goal of a monitoring methodology is to ensure that a secure water supply is provided to protect human beings from the effects of chemical and biological contaminants which may be accidentally or intentionally released 
into distribution systems. An important area of concern is the selection of optimal locations for monitors to provide the best capability for detecting contaminants. For regulatory and security concerns, water-quality sampling in distribution systems is of interest where, for example, Lee and Deininger (1992) conducted research in optimal placement of sensors. Optimization and heuristic tools monitoring locations in the distribution system have also been described in Ostfeld and Salomons (2004), Berry et al. (2005) and Murray et al. (2004) on sensor upstream coverage, which is determined by distribution system hydraulics. Nevertheless, a rational sampling and monitoring plan would account for not only the dynamic nature of distribution-system hydraulics, but also the conditions of distribution system components and their effect on water quality.

Cities and towns across North America are facing the problem of aging water infrastructure where many water infrastructure components have been in place for decades. Aging infrastructure increases the mechanical failure probability and, as a consequence, increases the probability of contamination ingress and the probability of water quality failure. Sensors can then be located at the places with higher probabilities and higher severities of water quality failure. Hence, the fault tree methodology developed above provides a simple and fast evaluation of the probability of water quality failure for a group of water distribution components. The probability or severity of water quality failure determined by the fault tree methodology thus can be used as one decision index in the placement of monitoring sensors.

Nevertheless, the problem still exists since existing sensors do not measure the microbiology. By existing regulations in Ontario, chlorine residual is checked once per day for several locations within the water distribution system. Typical scenarios to detect pathogens involve checking for E. coli and Total coli, at the frequency of twice/week, and once per week if chlorine is being used. However, the incubation and culture needed for these analyses is from one to several days to complete the analyses. For example, a determination of the indicator bacteria E. coli takes 24 hours, and an HPC count of the colonies takes from 3 to 7 days (Deininger et al., 2005). These tests have restricted utility for protection of the consumers in a timely fashion.

To allow a rapid local response, the goal of an early warning monitoring system is to reliably identify low probability/high impact contamination events in much faster times. One possibility for monitoring is to rely on an indirect or surrogate measurement, such as turbidity. Other instantaneous results include TOC, chlorine residual, and $\mathrm{pH}$. 
The possibility of a bioterrrorism event, or an ingress event, argues for water utilities to adopt easy and timely detection methods to protect the consumers against these undesirable events, by obtaining rapid measures. Some of these monitoring capabilities are being developed. For several years, portable waterproof UV probes which can measure turbidity, nitrate concentration, optical sensors, and UV absorption of water at 254 nanometers have been on the market (Weingartner, 2003). The spectrolyser is a spectrophotometer that records the absorption spectrum of a water sample in the 200-735 $\mathrm{nm}$ wavelength range (van den Broeke et al., 2006). However, these technologies have been in use primarily for monitoring surface water quality not for monitoring drinking water quality (van den Broeke et al., 2006).

Compared with the microbial detection method, detections for TOC, turbidity, chlorine residual concentration and $\mathrm{pH}$ are much easier and the instruments provide instantaneous results. Based on the knowledge that microbial contamination may impact these parameters, combinations of these parameters can be used to make inferences whether a microbial contamination event has occurred. Because the Bayesian methodology provides a basis of inference, a Bayesian framework can be employed to develop a classification method for contamination event identification.

According to Bayes' theorem:

$$
P(\theta \mid X)=\frac{P(X \mid \theta) \times P(\theta)}{P(X)}
$$

where:

$$
\begin{aligned}
\mathrm{X} & =\text { observed data; } \\
\theta & =\text { hypothesis; } \\
P(\theta \mid X)= & \text { the conditional probability of } \theta \text { given observed data } \\
& \mathrm{X} ; \\
P(\theta)= & \text { the prior probability without knowledge of } \mathrm{X} ; \\
P(X, Y \mid \theta) \times P(\theta)= & \text { the joint probability or so called likelihood; and } \\
P(X)= & \text { the prior probability without knowledge of } \theta .
\end{aligned}
$$

There are two competing hypotheses to detect the presence of pathogenic microorganisms in water distribution systems, contamination event (a) occurs and (b) does not occur. Assume that the finished water released at the treatment plant is free of any pathogens; the hypotheses can thus interpret whether or not pathogens are present in water distribution system. If a 
database as listed in Table 19.4 contains all the historical data from a drinking water treatment plant or in-situ tests, these data can be used to find a pattern which provides inferences whether or not pathogens are present in a water distribution system. The pattern can be further used to predict the presence of the pathogens in water from a new group of sensor data using a Bayesian classification method.

Table 19.4. Historical data from a drinking water treatment plant.

\begin{tabular}{llllll}
\hline Case & $\begin{array}{l}\text { TOC } \\
(\mathrm{mg} / \mathrm{L})\end{array}$ & $\begin{array}{l}\text { Turbidity } \\
(\mathrm{NTU})\end{array}$ & $\mathrm{pH}$ & $\begin{array}{l}\text { Chlorine } \\
(\mathrm{mg} / \mathrm{L})\end{array}$ & $\begin{array}{l}\text { Pathogen } \\
\text { present }\end{array}$ \\
\hline 1 & 0.3 & 1.3 & 7.2 & 0.3 & NO \\
2 & 1.5 & 2.3 & 7.3 & 0.26 & NO \\
3 & 2.4 & 4.5 & 7 & 0.1 & YES \\
4 & 5.6 & 5.6 & 6.5 & 0.05 & YES \\
5 & 2.8 & 3.2 & 6.8 & 0.15 & NO \\
6 & 8.7 & 5.6 & 7.5 & 0.15 & YES \\
7 & 2.3 & 0.3 & 6.8 & 0.25 & NO \\
8 & 1.8 & 3.1 & 6.9 & 0.35 & NO \\
9 & 2.7 & 2.0 & 7.1 & 0.2 & NO \\
10 & 3.0 & 0.8 & 7.3 & 0.22 & NO \\
11 & 9.1 & 1.8 & 6.5 & 0.18 & YES \\
12 & 0.9 & 7.5 & 7.5 & 0.24 & YES \\
13 & 1.6 & 2.3 & 6.6 & 0.22 & NO \\
14 & 2.1 & 3.5 & 6.7 & 0.3 & NO \\
15 & 2.0 & 2.0 & 7.1 & 0.29 & NO \\
\hline. & $\cdot$ &. & $\cdot$ &. &. \\
$\cdot$ &. &. & $\cdot$ &. &. \\
. &. &. &. &. &. \\
\hline
\end{tabular}

To use Bayes' theorem, the data shown in Table 19.4 need to be transformed into label (discrete) data. Table 19.5 lists the rules to transform the continuous data into discrete data. The rules should be defined by water utility based on the expert knowledge regarding the contamination effects on these water parameters.

Table 19.6 shows the results of data transformation using the transformation rules present in Table 19.5. After data transformation, using a data mining approach to analyze the historical database, these data may be classified into several classes. For instance, "select all where TOC is less than $1.0 \mathrm{mg} / \mathrm{L}$ and pathogens are present" or "select all where TOC is low and pathogens are present". Once obtained, the number of the records of a 
specified class, the probability of the specified class can be obtained. The probability of each class is summarized in Table 19.7 if the database only contains 15 data records as shown in Table 19.4.

Table 19.5 Transformation rules.

\begin{tabular}{lll}
\hline $\begin{array}{l}\text { Water } \\
\text { Parameters }\end{array}$ & Range & Label \\
\hline \multirow{2}{*}{ TOC } & $<=1.0$ & Low \\
& $1.0<$ and $<3.0$ & Medium \\
& 3.0 & High \\
\hline \multirow{2}{*}{ Turbidity } & $<=1.0$ & Low \\
& $1.0<$ and $<2.5$ & Medium \\
& $>=2.5$ & High \\
$\mathrm{pH}$ & $<=6.5$ & Low \\
& $6.5<$ and $<7.0$ & Medium \\
& $>=7.0$ & High \\
\hline & $<=0.1$ & Low \\
Chlorine & $0.1<$ and $<0.2$ & Medium \\
& $>=0.2$ & High \\
\hline
\end{tabular}

Table 19.6 Data after transformation.

\begin{tabular}{llllll}
\hline Case & TOC & Turbidity & $\mathrm{pH}$ & Chlorine & $\begin{array}{l}\text { Pathogen } \\
\text { present }\end{array}$ \\
\hline 1 & Low & Medium & High & High & NO \\
2 & Medium & Medium & High & High & NO \\
3 & Medium & High & High & Low & YES \\
4 & High & High & Low & Low & YES \\
5 & Medium & High & Medium & Medium & NO \\
6 & High & High & High & Medium & YES \\
7 & Medium & Low & Medium & High & NO \\
8 & Medium & High & Medium & High & NO \\
9 & Medium & Medium & High & High & NO \\
10 & High & Low & High & High & NO \\
11 & High & Medium & Low & Medium & YES \\
12 & Low & High & High & High & YES \\
13 & Medium & Medium & Medium & High & NO \\
14 & Medium & High & Medium & High & NO \\
15 & Medium & Medium & High & High & NO \\
\hline \multicolumn{5}{c}{ P(YES $=0.333$, P(NO $)=0.667$} &
\end{tabular}


Table 19.7 Probability of each class.

\begin{tabular}{lllll}
\hline $\mathrm{P}$ & $\mathrm{TOC}$ & Turbidity & $\mathrm{pH}$ & Chlorine \\
\hline $\mathrm{P}($ Low $\mid$ YES $)$ & 0.20 & 0.00 & 0.40 & 0.40 \\
$\mathrm{P}($ Medium |YES $)$ & 0.20 & 0.20 & 0.00 & 0.40 \\
$\mathrm{P}($ High|YES $)$ & 0.60 & 0.80 & 0.60 & 0.20 \\
$\mathrm{P}($ Low $\mid$ NO) & 0.10 & 0.20 & 0.00 & 0.10 \\
$\mathrm{P}($ Medium $\mid$ NO) & 0.80 & 0.50 & 0.50 & 0.10 \\
$\mathrm{P}($ High|NO) & 0.10 & 0.30 & 0.50 & 0.80 \\
\hline
\end{tabular}

According to Equation 19.3:

$$
P(Y E S \mid X)=\frac{P(X \mid Y E S) \times P(Y E S)}{P(X)}
$$

and

$$
P(N O \mid X)=\frac{P(X \mid N O) \times P(N O)}{P(X)} .
$$

Because $\mathrm{P}(\mathrm{X})$ is a constant, $P(\theta \mid X) \propto P(X \mid \theta) \times P(\theta)$. It means that if the likelihood $P(X \mid Y E S) \times P(Y E S)>P(X \mid N O) \times P(N O)$, then $\mathrm{P}(\mathrm{YES} \mid \mathrm{X})>\mathrm{P}(\mathrm{NO} \mid \mathrm{X})$, and vice versa.

Table 19.8 New data from sensors.

\begin{tabular}{llllll}
\hline Case & $\begin{array}{l}\text { TOC } \\
(\mathrm{mg} / \mathrm{L})\end{array}$ & $\begin{array}{l}\text { Turbidity } \\
(\mathrm{NTU})\end{array}$ & $\mathrm{pH}$ & $\begin{array}{l}\text { Chlorine } \\
(\mathrm{mg} / \mathrm{L})\end{array}$ & $\begin{array}{l}\text { Pathogen } \\
\text { present }\end{array}$ \\
\hline 16 & 0.2 & 2.4 & 6.5 & 0.3 & 16 \\
\hline 17 & 2.5 & 6.7 & 7.3 & 0.15 & 17 \\
\hline
\end{tabular}

Based on this knowledge, if a group of sensors in the water distribution system detects the following results as listed in Table 19.8, using the class probability identified in Table 19.7, the likelihoods of YES and NO can be calculated as summarized in Table 19.9. Cases 16 and 17 are identified to be NO and YES, respectively. 
Table 19.9 Likelihood of pathogens.

\begin{tabular}{llll}
\hline Case & $\begin{array}{l}\mathrm{P}\left(\mathrm{X}_{\mathrm{i}} \mid \mathrm{YES}\right) \\
\mathrm{P}(\mathrm{YES})\end{array}$ & $\begin{array}{l}\mathrm{P}\left(\mathrm{X}_{\mathrm{i}} \mid \mathrm{NO}\right) \\
\mathrm{P}(\mathrm{NO})\end{array}$ & $\begin{array}{l}\text { Presence of } \\
\text { Pathogens }\end{array}$ \\
\hline 16 & 0.001 & 0.013 & NO \\
\hline 17 & 0.011 & 0.006 & $\mathrm{YES}$ \\
\hline
\end{tabular}

\subsection{Conclusions}

This research has identified four types of water quality failures in water distribution systems, namely contamination ingress, microbial regrowth, chemical and corrosion product leaching from pipes, chlorine residual not being maintained. A fault tree which represents the water quality failure mechanism in water distribution systems has been developed. A fault tree methodology to quantify the water quality failure probability in water distribution systems is developed, and applied to analysis of groundwater ingress. This method can be applied as one index in locating on-line sensors in water distribution systems. A combination of sensors is proposed to provide a timely response to a contamination event and to improve the current microbial detection method. A Bayesian classification method, in conjunction with data mining procedure, is developed to evaluate sensor data and develop inferences whether pathogens are present in water distribution system.

\section{References}

Berry, J., L. Fleisher, W. Hart, C. Phillips, and J. Watson. ( 2005). "Sensor Placement in Municipal Water Works", J, WRPM, ASCE, 131(3), 237-243

Deininger, R.A., J. Lee and J. Min. 2005. "Rapid Detection of Bacteria in a Water Distribution System." Journal of Water Management Modeling R223-04. doi: 10.14796/JWMM.R223-04.

Eisnor, J.D. and G. A. Gagnon. (2003). "A Framework for the Implementation and Design of Pilot-Scale Distribution Systems." Journal of Water Supply and Technology-Aqua, 52(7), 501-519.

Huang, J., and E. McBean. (2006). "Using Bayesian Statistics to Estimate the Chlorine Wall Decay Coefficients for a Water Distribution System", submitted to Journal of Water Resources Planning and Management, ASCE. 
Huang, J., E. McBean and W. James. 2005. "A Review of Reliability Analysis for Water Quality in Water Distribution Systems." Journal of Water Management Modeling R223-07. doi: 10.14796/JWMM.R223-07.

Kramer, M. H., B.L. Herwaldt, R.J. Calderon, D.D. Juranek. (1996). "Surveillance for Waterborne-Disease Outbreaks -- United States, 1993-1994", US CDC, http://www.cdc.gov/mmwr/preview/mmwrhtml/00040818.htm

Lee, B. H. and R.A. Deininger. (1992). "Optimal Locations of Monitoring Station in Water Distribution System”, Journal of Environmental Engineering, 118(1), 4-17

Ministry of the Attorney General Ontario. (2002). "Walkerton Commission of Inquiry Reports", http://www.attorneygeneral.jus.gov.on.ca/english/about/pubs/walkerton/

McBean, E.A., and F. Rovers. (1998). Statistical Procedures for Analysis of Environmental Monitoring Data and Risk Assessment, Prentice Hall Publishing Co. Inc., Englewood Cliffs, New Jersey

Murray, R., R. Janke, and J. Uber. (2004). The Threat Ensemble Vulnerability Assessment (TEVA) Program for Drinking Water Distribution System Security", Proceedings, EWRI World Water \& Environmental Resources Congress, ASCE, Salt Lake City, UT

Ostfeld, A., and E. Salomons. (2004). "A Stochastic Early Warning Detection System Model for Drinking Water Distribution Systems Security", Proceedings EWRI World Water \& Environmental Resources Congress, ASCE, Salt Lake City, UT

Perz, J., K. Ennever, and S. LeBlancq. (1998). "Cryptosporidium in Tap Water." American Journal of Epidemiology, Vol. 147, No. 3 pp 289-301

Rose, J. (2002). "Water Quality Security", Environmental Science and Technology, 36:247A.

Rossman, L. A., R. Clark, and W. Grayman. (1994) "Modelling Chlorine Residuals in Drinking Water Distribution Systems." Journal of Environmental Engineering, 120(4), 803-817.

Schuster, C., J. Aramini, A. Ellis, B. Marshall, W. Robertson, D. Medeiros, and D. Charron. (2005). "Infectious Disease Outbreaks Related to Drinking Water in Canada, 1974-2001", Canadian Journal of Public Health, Jul/Aug. 96, 4, 254-258

USC FCCCHR. (1993). Foundation for Cross-Connection Control and Hydraulic Research, USC, Manual of Cross-Connection Control Volume 9 LA, California

US EPA. (2002)."Potential Contamination Due to Cross-Connections and Backflow and the Associated Health Risks", Office of Groundwater and Drinking Water, August.

Wable, O., N. Dumoutier, J.P. Duguet, G. Gelas, and J.F. Depierre. (1991). "Modelling Chlorine Concentration in a Network and Applications to Paris Distribution Network." Proc., Water Quality Modelling in Distribution Systems Conference, AWWA Research Foundation, Denver, Colo.

Weingartner, A. (2003). "New Application of S::Can's Ultra Compact Submersible UVvis-spectrometers", Int Env Tech., 13(2), 146

Van den Broeke, J., A. Brandt, A. Weingartner, and F. Hofstadter. (2006) "Monitoring of Organic Micro Contaminants in Drinking Water Using a Submersible UV/Vis spectrophotometer", ed J. Pollert and B.Dedus, The NATO Programme for Security through Science, Springer Press, The Netherlands. 
